\title{
ANALISIS NILAI TAMBAH PRODUK TAHU DARI KEDELAI DI KELURAHAN SUNGAI BESAR KECAMATAN BANJARBARU SELATAN KOTA BANJARBARU PROVINSI KALIMANTAN SELATAN
}

\author{
(Analysis of Added Value of Tofu From Soybean Products in Sungai Besar Village, South \\ Banjarbaru Sub-District, Banjarbaru District, South Kalimantan Province)
}

\section{Zuraida}

Program Studi Agribisnis Fakultas Pertanian Universitas Achmad Yani Banjarmasin Jl. A Yani Banjarbaru

Article Submitted : 29-10-2018

Article Accepted : 13-01-2019

\begin{abstract}
The Purpose of this Study was to Determine the Extent to which the Process of Processing Soybeans into Processed Products,Namely Tofu that can Provide a level of Profit and added Value for Businesses in the Study Area. Data Collection was Done by Purposive Sampling method (Deliberately). The Results showed that the Tofu Processing Process was Carried out Using Simple Technology,Namely Using the Main Raw Material of Soybeans. Mashed with added Vinegar and Salt Acid with a Simple Tool.As for the Amount of Soybean Raw Material once the Production is an Average of $133,33 \mathrm{~kg}$ Per day With $226,61 \mathrm{~kg}$ of Tofu. Workforce $6,90 \mathrm{HOK}$ with Labor out of 0,052 HOK Per kg of Soybeans to Know in Return for Rp 5.460 Added Value of Rp 7.164,02 per $\mathrm{kg}$ with a Ratio of Added Value Obtained 42,89\% of the output Value means that Every Rp 100 output Values Will Get an Added Value of 42,89 Which is Include in the Category of High Added Value. Profits are Obtained in the Amount of Rp1 .704,02 with a Ratio of 23,79\% to Added Value.
\end{abstract}

Keywords : Soybean, Tofu, Added Value

\section{PENDAHULUAN}

Berdasarkan potensi di wilayah Kalimantan Selatan yang sangat luas dan cukup banyak yang baik untuk budidaya pertanian secara umum, namun tanaman kedelai memang belum banyak dibudidayakan oleh petani, walau ada petani yang membudidayakan tapi hasil produksinya masih belum maksimal baik kuantitas maupun kualitas dan jauh dari yang diharapkan, sehingga belum dapat memenuhi kebutuhan atau permintaan pasar di daerah ini.

Sementara itu, produksi kedelai di Kalsel sepanjang tahun 2015 sebesar 10,53 ribu ton mengalami kenaikkan sebanyak 1.591 ton atau 17,78 ton jika dibanding tahun2014. Kenaikkan disebabkan peningkatan luas panen sebesar 874 hektare atau 12,76 persen dan adanya peningkatan produktivitas sebesar 0,59 kuintal per hektare atau 4,52 persen,. Produksi kedelai di Kalsel tersebar 11 kabupaten yaknii Kabupaten Kotabaru 25,10 persen, Tanah Laut 24,46 persen, Banjar 13,07 persen, Tabalong 10,15 persen, (Antara Kal-Sel 2016).

Tetapi produksi dan supply kedelai dii Kalimantan selatan tidak dapat memenuhi tingkat permintaan pasar, karena disamping produksi tidak maksimal baik kualitas maupun kuantitas juga petani kurang berminat untuk menanam kedelai secara terus menerus, karena dalam budidaya kedelai memerlukan pemelihaan dan perhatian yang sangat intensif. Budidaya kedelai harus menyesuaikan dengan musim dan tifologi 
lahan di Kalimantan Selatan yang kurang mendukung, dan juga komoditi kedelai belum menjadi komoditas pertanian yang menarik bagi petani Kalsel karena dinilai kurang menguntungkan.

Kedelai sebagai bahan baku pembuatan tempe dan tahu serta produk turunann lainnya seperti kecap, susu kedelai khususnya di daerah Kota Banjarbaru kebutuhan kedelai masih dipenuhi dari luar daerah terutama dari pulau jawa, sehingga harga kedelai sangat tergantung dari tingkat supply dan demand di daerah ini, yang nantinya akan berdampak kepada harga produk turunannya seperti tahu, tempe di pasaran.

Sekarang petani banyak yang belum melaksanakan pengolahan hasil pertaniannya dengan baik dengan berbagai alasan, padahal disadari bahwa kegiatan pengolahan hasil pertanian ini diangggap cukup penting karena dapat meningkatkan nilai tambah.Salah satu usaha dalam peningkatan nilai tambah produk kedelai di daearah ini adalah dengan pegolahan hasil seperti pembuatan tempe, tahu dan susu kedelai yang banyak dikonsumsi masyarakat kita sebagai minuman dan makanan tradisional pelengkap lauk pauk dan camilan. Bahan baku pembuatan tempe menggunakan kedelai yang merupakan bahan makanan penting sebagai sumberproteinnabati.

Prospek usaha pembuatan tahu ini sangat baik dan menguntungkan, bahkan sampai sekarang tahu mulai dikenal dan diminati merupakan salah satu makanan tradisional yang popular dimasyarakat. Meskipun harganya murah dan bentuknya sederhana ternyata tahu mempunyai nilai gizi yang sangat baik yang ideal untuk makanan diet, rendah kandungan lemak jenuh dan bebas kholesterol, kaya mineral dan vitamin. Kandungan gizi kedelai per 100 gram yaitu Kalori $331 \mathrm{kcal}$, Air 7,5 gram, Protein 34 gram, Lemak 18,1 gram, Karbohidrat 34,8 gram, Kalsium $227 \mathrm{mg}$, Fosfor $585 \mathrm{mg}$, Besi 8 mg,Vitamin A110 SI dan Vitamin B1 1,1 mg (Hartoyo,2006).
Tidak kalah pentingnya proses pengolahan kedelai menjadi produk tahu umumnya masih secara tradisional yang menggunakan peralatan yang sederhana seperti mesin pengupas, penggiling, tempat air, tempat memasak, tungku dan alat cetakan. Sedangkan penggunaan tenaga kerja adalah anggota keluarga dan masyarakat sekitar yang dengan upah yang relatif tetap.Tetapi Gejolak harga kedelai yang sering terjadi dapat memberikan dampak bagi industri pengolahan tahu yang masih dalam skala kecil dan rumah tangga ini sehingga dapat menyebabkan penerimaan dan pendapatan pengrajin menurun seiring turun naiknya harga kedelai karena biaya produksi tahu yang dikeluarkan meningkat, walaupun para pengrajin telah menaikkan harga jualnya.

Dari permasalahan di atas kiranya perlu diteliti aspek finansial sejauh mana nilai tambah kacang kedelai pada pengolahan tahu yang melibatkan beberapa faktor produksi dan sarana produksi dalam mendukung proses produksi tahu di daerah ini.

\section{METODE PENELITIAN}

\section{Waktu dan tempat penelitian}

Penelitian ini dilakukan di Kelurahan Sungai Besar Kecamatan Banjarbaru Selatan Kota Banjarbaru. Adapun usaha pengolahan Tahu yang ada di daerah ini berjumlah 10 buah, dan peneliti hanya mengambil sampel dua usaha pengrajin pengolah tahu secara sengaja.Penelitian ini berlangsung dari bulan Agustus 2017 sampai dengan bulan September 2017, yaitu mulai dari persiapan, pengumpulan data sampai dengan tahapan penyusunan laporan.

\section{Metode PengumpulanSampel}

Pengumpulan data dilakukan dengan metode survei dengan sengaja (purposive sampling) yang usahanya dianggap skala kapasitas produksinya lebih besar setiap bulannya. Datayang dikumpulkan berupa data primer dan sekunder. Data primer dikumpulkan melalui wawancara langsung dengan pelaku usaha pengolahan tahu, dengan 
menggunakan daftar pertanyaan yang telah dipersiapkan terlebih dahulu. Dataprimer tersebut terdiri dari identitas pengrajin dan penyelenggara usaha proses pembuatan tahu yang meliputi persiapan bahan baku dan bahan penolong, proses pembuatan tahu, menganalisis biaya, keuntungan serta nilai tambah yang diperoleh. Adapun data sekunder diperoleh dari dinas-dinas atau instansi yang ada hubungannya dengan penelitian ini.

\section{Analisis Data}

Pada analisa usaha pengolahan tahu maka perlu penyederhanaan data agar mudah dibaca dalam bentuk tabulasi. Alur analisa data dapat dihitung dan ditampilkan serta dianalisis menggunakan metode deskriptif untuk diinterpretasikan menggunakan analisis biaya, penerimaan, keuntungan, dan analisis nilai tambah sederhana metode Hayami.

Analisis Finansial Usaha Pembuatan Tahu meliputi : Analisis biaya dalam unit usaha yang dapat dilakukan dengan menggunakan formula Total Cost (TC), Total Revenue (TR) dan Profit (П) menurut Sugiarto, dkk. (2005).

Total Cost (TC) adalah keseluruhan biaya yang dikeluarkan dalam menghasilkan output

dimana :

$$
\mathrm{TC}=\mathrm{FC}+\mathrm{VC}
$$

$\mathrm{FC}=$ Fixed Cost/ Biaya Nyata

$\mathrm{VC}=$ Variable Cost $/$ Biaya Tidak Tetap

Total Revenue (TR) adalah jumlah penerimaan suatu usaha yang diperoleh dari besarnya tingkat produksi dikalikan dengan tingkat harga.

dimana :

$$
\mathrm{TR}=\mathrm{P} \times \mathrm{Q}
$$

$\mathrm{P}=$ Price/ Harga

$\mathrm{Q}=$ Quantity/Jumlah Produksi

Analisis nilai Tambah pada penelitian

ini menggunakan metode analisis nilai tambah menurutmetode hayami pengolahan dengan formula seperti Tabell.
Tabel 1. Perhitungan Nilai Tambah Metode

\begin{tabular}{|c|c|c|}
\hline \multirow{2}{*}{\multicolumn{3}{|c|}{$\begin{array}{c}\text { Variabel } \\
\text { Output, Input dan Harga }\end{array}$}} \\
\hline & & \\
\hline 1. & $\begin{array}{l}\text { Output yang dihasilkan } \\
\text { (kg/hari) }\end{array}$ & $\mathrm{a}$ \\
\hline 2. & $\begin{array}{l}\text { Bahan baku yang digunakan } \\
\text { (kg/hari) }\end{array}$ & $\mathrm{b}$ \\
\hline 3. & Tenaga Kerja (Jam/hari) & $\mathrm{c}$ \\
\hline 4. & Faktor konversi $(1 / 2)$ & $d=a / b$ \\
\hline 5. & Koefisien Tenaga Kerja (3/2) & $\mathrm{e}=\mathrm{c} / \mathrm{b}$ \\
\hline 6. & Harga Output (Rp/kg) & $\mathrm{f}$ \\
\hline 7. & $\begin{array}{l}\text { Upah Rata-rata Tenaga Kerja } \\
\text { (Rp/jam) }\end{array}$ & $\mathrm{g}$ \\
\hline & Pendapatan dn Keuntungan & \\
\hline 8. & $\begin{array}{l}\text { Harga Bahan Baku (Rp/kg } \\
\text { bahan baku) }\end{array}$ & $\mathrm{h}$ \\
\hline 9. & $\begin{array}{l}\text { Sumbangan infut lain ( } \mathrm{Rp} / \mathrm{kg} \\
\text { output) }\end{array}$ & $\mathrm{i}$ \\
\hline 10. & Nilai Output (4 x 6) Rp & $\mathrm{j}=\mathrm{d} \times \mathrm{f}$ \\
\hline & $\begin{array}{l}\text { a. Nilai Tambah }(10-9-8) \\
\text { (Rp) }\end{array}$ & $\mathrm{k}=\mathrm{j}-\mathrm{h}-\mathrm{i}$ \\
\hline & $\begin{array}{l}\text { b. Ratio Nilai Tambah } \\
(11 \mathrm{a} / 10) \times 100 \%\end{array}$ & $\begin{array}{c}1(\%)=\mathrm{k} / \mathrm{j}) \mathrm{x} \\
100 \%\end{array}$ \\
\hline 12. & $\begin{array}{l}\text { a. Imbalan Tenaga Kerja (5x } \\
\text { 7) } \mathrm{Rp}\end{array}$ & $\mathrm{m}=\mathrm{e} \times \mathrm{g}$ \\
\hline & $\begin{array}{l}\text { b. Bagian Tenaga kerja } \\
(12 a / 11 a) \times 100 \%\end{array}$ & $\begin{array}{c}\mathrm{n}(\%)=(\mathrm{m} / \mathrm{k}) \\
\quad \times 100 \%\end{array}$ \\
\hline 13. & $\begin{array}{l}\text { a. Keuntungan }(11 a-12 a) \\
(\mathrm{Rp})\end{array}$ & $\mathrm{o}=\mathrm{k}-\mathrm{m}$ \\
\hline & $\begin{array}{l}\text { b. Tingkat Keuntungan } \\
(13 a / 11 a) \times 100 \%\end{array}$ & $\begin{array}{c}\mathrm{p}(\%)=(\mathrm{o} / \mathrm{k}) \mathrm{x} \\
100 \% .\end{array}$ \\
\hline
\end{tabular}
Hayami.

Sumber; Hayami dalam Sharfina dkk (2015)

Kriteria tingkat ratio nilai tambah menurut Hubeis, 1997 yakni:

1. Jika besarnya ratio nilai tambah $<15 \%$, maka nilai tambahnya rendah.

2. Jika besarnya ratio nilai tambah $15 \%$ $49 \%$, maka nilai tambahnya sedang.

3. Jika besarnya ratio nilai tambah $>40 \%$, maka nilai tambahnya tinggi.

\section{HASIL DAN PEMBAHASAN}

\section{Keadaan Umum Daerah Penelitian}

Kelurahan Sungai Besar Kecamatan Banjarbaru Selatan Kota Banjarbaru yang dekat dengan pusat pemerintahan, tentunya didominasi pemukiman, infrastruktur dan fasilitas umum.Tingkat pendidikan masyarakat cukup tinggi karena kota Banjarbaru merupakan pusat kota pendidikan 
di Kalimantan Selatan, sehingga aktivitas perekonomian sejalan dengan bertambahnya penduduk, dan mata pencaharian masyarakatnya beragam seperti PNS, pedagang, jasa dll. Industri rumahan atau rumah tangga merupakan pencaharian sampingan yang banyak dilakukan masyarakat disini.

\section{Identitas dan Profil Usaha}

Gambaran umum mengenai latar belakang usaha pengrajin tahu merupakan faktor penting untuk mengetahui karakteristik dan identitas responden, dimana dua usaha pengrajin tahu ini dapat diketahui usia, tingkat pendidikan, jumlah tanggungan, serta pengalaman dan motivasi dalam berusaha dibidang pengolahan tahu ini.

Pemilik usaha pengolahan tahu termasuk jenis usaha perorangan milik sendiri masing-masing berbentuk Usaha Dagang, dengan usia sekitar 43 tahun dengan tingkat pendidikan lulus SMP SMA/sederajat, seperti pada Tabel 2 ini.

Tabel 2. Profil Usaha Pengolah Tahu

\begin{tabular}{|c|c|c|c|c|c|c|}
\hline \multirow{2}{*}{$\begin{array}{l}\text { Nama } \\
\text { Usaha } \\
\text { (UD) }\end{array}$} & \multirow{2}{*}{$\begin{array}{l}\text { Usia } \\
\text { (th) }\end{array}$} & \multirow{2}{*}{$\begin{array}{l}\text { Tanggu } \\
\text { ngan } \\
\text { (Orang }\end{array}$} & \multicolumn{2}{|c|}{ TK } & \multirow{2}{*}{$\begin{array}{l}\text { Kapasit } \\
\text { as Pro } \\
\text { duksi/ } \\
\text { hari } \\
(\mathrm{kg})\end{array}$} & \multirow{2}{*}{$\begin{array}{l}\text { Lama } \\
\text { Usaha } \\
\text { (th) }\end{array}$} \\
\hline & & & $\begin{array}{l}\text { DK } \\
\text { (hok) }\end{array}$ & $\begin{array}{l}\text { LK } \\
\text { (hok) }\end{array}$ & & \\
\hline Baihaki & 40 & 3 & 2 & 5,5 & 150 & 14 \\
\hline $\begin{array}{l}\text { Tahu } \\
\text { Balap }\end{array}$ & 50 & 3 & 2 & 4,3 & 116,66 & 15 \\
\hline
\end{tabular}

Sumber: Pengolahan data primer (2018)

Adapun jumlah tanggungan terdiri dari 3 orang satu isteri dan anak-anaknya yang masih sekolah.Usaha ini sudah dilaksanakan kurang lebih 14 tahun berjalan.Dilihat dari pengalaman usaha maka motivasi responden tentunya ingin terus memproduksi tahu dalam menyediakan tahu yang sehat dan berkualitas dengan harga yang terjangkau agar dapat memenuhi kebutuhan gizi masyarakat sekitarnya.Tentunya dari segi finansial juga mendapat keuntungan bagi kelangsungan usahanya.

Berdasarkan observasi bahan baku yaitu kedelai yang digunakan dalam pembuatan tahu disini adalah kedelai kuning, karena dapat menghasilkan tahu yang berkualitas tinggi.Kebutuhan kedelai yang dipasok dari pasar induk mencapai $4000 \mathrm{~kg}$ dalam 25 sampai 30 kali produksi. Bahan baku kedelai ini harus dipesan dari jauh hari sebelum produksi, karena ketersediaannya tergantung dari luar daerah dan juga harga kedelai berfluktuasi juga dipengaruhi oleh tingkat supply kedelai dipasar. Sedangkan sarana produksi lainnya yang habis pakai dalam pembuatan tahu adalah kayu bakar, garam, air, cuka dan yang dihitung sebagai biaya produksi

Usaha pengolahan tahu disini yang merupakan indutri kecil atau rumah tangga mampu menciptakan lapangan kerja sedangkan tenaga kerja yang dipekerjakan berasal dari tenaga kerja dalamkeluarga dan tenaga kerja dari lingkungan sekitar rata-rata berjumlah tujuh (7) orang baik laki-laki maupun perempuan. Jumlah tenaga kerja ini disesuaikan dengan kapasitas produksi yang akan dilakukan. Karena proses pembuatan tahu ini lebih rumit dan menggunakan tenaga kerja yang banyak bila dibandingkan dengan pembuatan tempe. Sedangkan upah tenaga kerja besarannya berdasarkan satuan Hari orang Kerja (HOK), yaitu jumlah orang dikali hari kerja dikali jam kerja dibagi jam kerja standar, dimana jam kerja standar usahatani 7 jam dan diluar usahatani 8 jam (Dinas Ketenagakerjaan dan Transmigrasi, 2007). Adapun kegiatan yang dilakukan tenaga kerja disini meliputi sortir dan cuci kedelai, menggiling dan merebus, menyaring dan mencetak.

Proses pengolahan tahu di dearah ini masih secara sederhana dan tradisional, yang secara umum menggunakan peralatan seperti mesin penggiling, tungku dan panci besar untuk memasak bubur kedelai, kain penyaring dan cetakan kayu, mesin air, tong besar dan lain-lain, yang kesemuanya dihitung berdasarkan nilai penyusutan alat. Langkahlangkah proses pengolahan tahu secara sederhana oleh responden sebagai berikut: 


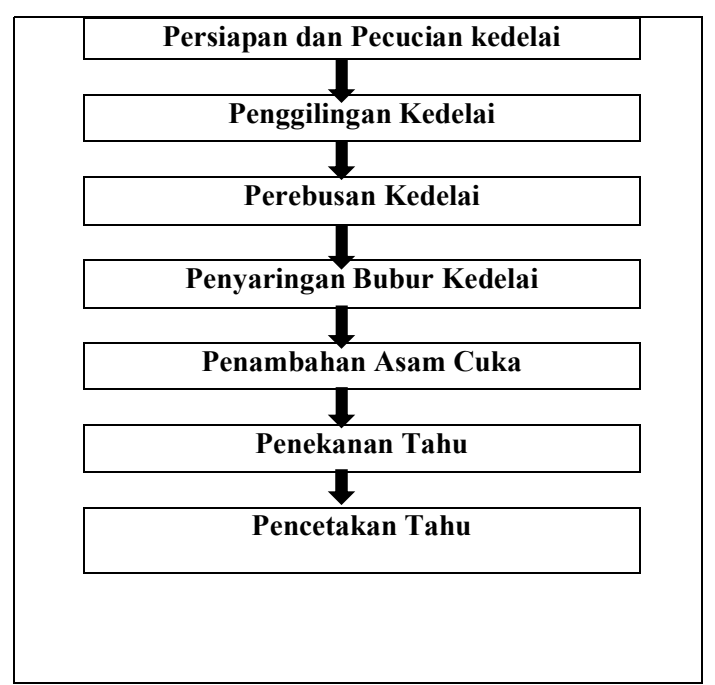

Gambar 1. Proses Pembuatan Tahu

\section{Analisis Nilai Tambah Pengolahan Tahu}

Proses pengolahan tahu di daerah penelitian mulai dari perendaman, penggilingan, perebusan kacang kedelai hingga penyaringan dan pencetakan merupakan suatu rangkaian kegiatan agribisnis dalam kegiatan pengolahan kacang kedelai yang sebelumnya dalam bentuk bijian yang diolah menjadi tahu yang siap untuk dikonsumsi masyarakat. Disini terjadi penciptakan suatu nilai produk olahan (tahu) atau nilai tambah terhadap biji kedelai tsb.Selanjutnya untuk hasil analisisnya dapat dilihat pada Tabel 3 berikut.

Tabel 2. Analisis Nilai Tambah Pengolahan Tahu di Kelurahan Sungai Besar Kota Banjarbaru per hari

\begin{tabular}{lll}
\hline \multicolumn{1}{c}{ Variabel } & Penilaian \\
\hline & Output, Input dan Harga & \\
1. & Output yang dihasilkan (kg/hari) & 223,69 \\
2. & $\begin{array}{l}\text { Bahan baku yang digunakan } \\
(\mathrm{kg} / \mathrm{hari})\end{array}$ & 133,33 \\
3. & Tenaga Kerja $(\mathrm{HKO})$ & 6,90 \\
4. & Faktor konversi $(1 / 2)$ & 1,67 \\
5. & Koefisien Tenaga Kerja (3/2) & 0,052 \\
6. & Harga Output (Rp/kg) & $10.000,00$ \\
7. & Upah Rata-rata Tenaga Kerja & 105.000 \\
& (Rp/HKO) & \\
Pendapatan dn Keuntungan & \\
8. $\begin{array}{l}\text { Harga Bahan Baku (Rp/kg bahan } \\
\text { baku) }\end{array}$ & $7.500,00$ \\
& & $2.035,98$ \\
\hline
\end{tabular}

\begin{tabular}{|c|c|c|}
\hline 9. & $\begin{array}{l}\text { Sumbangan infut lain }(\mathrm{Rp} / \mathrm{kg} \\
\text { output) }\end{array}$ & $16.700,00$ \\
\hline 10. & Nilai Output $(4 \times 6)$ & $7.164,02$ \\
\hline 11. & $\begin{array}{l}\text { a.Nilai Tambah }(10-9-8)(\mathrm{Rp}) \\
\text { b.Ratio Nilai Tambah }(11 \mathrm{a} / 10) \mathrm{x}\end{array}$ & 42,89 \\
\hline & $100 \%$ & 5.460 \\
\hline 12. & $\begin{array}{l}\text { a. Imbalan Tenaga Kerja }(5 \times 7) \\
\text { b. Bagian Tenaga kerja }(12 \mathrm{a} / 11 \mathrm{a})\end{array}$ & 76,21 \\
\hline & x $100 \%$ & $1.704,02$ \\
\hline 13. & $\begin{array}{l}\text { a. Keuntungan }(11 a-12 a)(R p) \\
\text { b.Tingkat Keuntungan }(13 a / 11 a) \\
\text { x } 100 \%\end{array}$ & 23,79 \\
\hline
\end{tabular}

Dari perhitungan nilai tambah dengan menggunakan metode Hayami atas dasar perhitungan dalam kilogram bahan baku di Kelurahan Sungai Besar Kecamatan Banjarbaru Selatan maka diperoleh hasil sebagai berikut, berdasarkan Tabel 3 di atas diketahui dalam penggunaan bahan baku kacang kedelai sebanyak 133,33 kgakan dapat menghasilkan tahu sebesar $223,69 \mathrm{~kg}$ per haridengan mencurahkan tenaga kerja sebesar 6,9 HOK per harinya.Tenaga kerja yang dibutuhkan untuk mengolah setiap satu kilogram kedelai menjadi tahu yaitu0,052 HOK per hari. Sedangkan setiap kilogram pengolahan kacang kedelai menjadi tahu memberikan imbalan yang diterima tenaga kerja langsung sebesar Rp 5.460,00, dengan demikian bagian tenaga kerja dalam pengolahan kedelai menjadi tahu ini sebanyak 76,21 persen, yang merupakan komponen biaya yang terbesar setelah bahan baku kacang kedelai.

Apabila nilai output sebesar Rp $10.000,00 / \mathrm{kg}$, dan nilai faktor konversi sebesar 1,67 maka nilai produksi $\mathrm{Rp}$ 16.700,00. Nilai produksi ini dialokasikan untuk bahan baku kedelai seharga $\mathrm{Rp}$ $7.500,00$ dan bahan penolong dan lainnya sebesar Rp 2.035,98 per kilogram output. Analisis lebih lanjut menunjukkan bahwa tingkat keuntungan yang didapat dari pengolahan kedelai menjadi tahu sebesar 23,79 persen. Walau keuntungan saat ini cukup kecil,bila dibandingkan beberapa waktu yang lalu dimana harga bahan baku kedelai masih berada dikisaran 6000,00 
sampai dengan 6300,00 per kilogramnya. Pada saat penelitian ini dilakukan harga kacang kedelai sudah mencapai Rp 7.500,00 perkilogramnya, hal ini karena kebutuhan kacang kedelai kita masih tergantung impor, dan gejolak kurs rupiah melemah mengakibatkan harga kacang kedelai meningkat menjadi Rp 7.000,00 sampai dengan Rp 7.500,00 per kilogram, dengan tingkat harga jual output tahu yang relatif tetap. Saat ini tingkat keuntungan mengalami penurunan, tapi usaha masih tetap dapat berjalan.Dengan demikian harga bahan baku dan jumlah tenaga kerja yang digunakan sangat mempengaruhi tingkat penerimaan dan keuntungan yang didapat oleh pelaku usaha saat ini. Keuntungan ini menunjukkan bagian yang diterima pelaku usaha karena menanggung resiko usaha, dan Hayami, et al (1987) menyatakan bahwa tingkat keuntungan sebesar 23.79 persen merupakan persentase keuntungan terhadap nilai tambah. Sedangkan nilai tambah yang tercipta dari setiap kilogram kacang kedelai menjadi tahu di Kelurahan Sungai Besar akan diperoleh sebesar Rp 7.164,02 yang merupakan selisih antara nilai output dengan bahan baku dan sumbangan input lainnya, artinya setiap satu kilogram kacang kedelai setelah mengalami proses produksi mampu memberikan nilai tambah sebesar $\mathrm{Rp}$ $7.164,02$ per kilogram. Sedangkan rasio nilai tambah yang diperoleh 42,89 persen yang menunjukkan persentase nilai tambah terhadap nilai produksi, artinya setiap $\mathrm{Rp}$ 100,00 nilai output akan mendapatkan nilai tambah sebesar Rp 42,89. Nilai tambah yang dihasilkan merupakan nilai tambah kotor karena nilai tambah tersebut masih mengandung bagian untuk pendapatan tenaga kerja.

dalam kategori nilai tambah tinggi, dibandingkan hasil penelitian Sitri dkk nilai tambah masih dibawah yaitu 30,64\%. Sebaliknya dengan nilai tambah kedelai diolah menjadi tempedan kedelai diolah menjadi susu kedelai yakni lebih tinggi, hal ini karena proses pengolahan tahu lebih rumit dari proses kedelai menjadi tempe dan susu kedelai.

Keuntungan dan nilai tambah ini dapat ditingkatkan lagi apabila dapat menekan dua komponen biaya tersebut seperti stabilnya harga bahan baku kacang kedelai dan dapat mengefisienkan penggunaan tenaga kerja dalam proses produksi tahu ini.

\section{KESIMPULAN DAN SARAN}

\section{Kesimpulan}

Berdasarkan hasil penelitian maka didapat kesimpulan sebagai berikut:

1. Usaha Pengolahan tahu di Kelurahan Sungai Besar Banjarbaru ini dengan rata-rata jumlah bahan baku 133,33 kg kacang kedelai akan menghasilkan tahu 223, $69 \mathrm{~kg}$ per hari, dengan curahan tenaga kerja 0,052 HOK per kilogram kacang kedelai menjadi tahu dengan imbalan upah sebesar Rp 5.460,00.Keuntungan yang didapat sebesar Rp 1.704,02 dengan rasio 23,79 persen terhadap nilai tambah

2. Nilai tambah yang diperoleh dalam usaha pengolahan kacang kedelai menjadi tahu di daerah ini sebesar $\mathrm{Rp}$ 7.164,02 per kilogramyang merupakan selisih antara nilai output dengan bahan baku dan sumbangan input lainnya, dengan rasio nilai tambah yang diperoleh 42,89 persenterhadap nilai output, artinya setiap Rp 100,00 nilai output akan mendapatkan nilai tambah sebesar Rp 42,89. termasuk dalam kategori nilai tambah tinggi.

3. Permasalahan yang dihadapi pada Usaha Pengolahan tahu UD BAIHAKI dan UD TAHU BALA Padalah harga bahan baku kacang kedelai yang sedang naik dan biaya produksi yang terlampau tinggi sedangkan harga tahu dipasaran sulit untuk dinaikkan sehingga mempengeruhi penerimaan dan keuntungannya. 


\section{Saran}

1. Untuk meningkatkan pendapatan dan keuntungan dan meningkatkan nilai tambah pelaku usaha pengolahan tahu, maka perlu adanya efisiensi dalam penggunaan tenaga kerja.

2. Bagi Instansi terkait perlu dilakukan bimbingan teknis yang efisien, higienis dan motivasi variatif output secara berkelanjutan,agar mereka dapat meningkatkan produktivitas usaha.

3. Pemerintah dalam hal kebijakan bisa memberikan jalan agar harga kacang kedelai tidak berfluktuatif sehingga pelaku usaha pengolahan kacang kedelai tidak merasa cemas dan menjamin ketersediaan bahan baku dipasaran dengan harga yang wajar dan stabil.

\section{DAFTAR PUSTAKA}

Anonim.Dinas Ketenagakerjaan dan

Transmigrasi, 2007

Antara Kal Sel.com hari Rabu tanggal 20

Sept 2017.

https://kalsel.antaranews.com

Hartoyo, A. Dan F.H. Sunandar. 2006. Pemanfaatan tepung komposit Ubi Jalar Putih, Kecambah Kedelai (Glycine max merr) dan Kecambah Kacang hijau Sebagai Substituen Farsial Terigu Dalam Produk Pangan Alternatif BiskuitKala Energi Protein. Jurnal Teknologi dan Industri Pangan, Vol XVII No. I Th. 2006.
Sharfina dkk.2015. Analisis Finansial Usahatani Kedelai dan Nilai Tambah Tahu di Kabupaten Lombok Tengah.Jurnal SEPA Volume 12 No.1 September 2015: 11-18.

Hubeis M. 1997.Menuju Industri Kecil Profesional di Era Galobalisasi melalui Pemberdayaan Manajemen Industri.Orasi Ilmiah Guru Besar Tetap Ilmu Manajemen Industri. Fakultas Teknologi Pertanian. IPB Bogor.

Nazir, M. 2011. Metode Penelitian. Ghalia Indonesia. Bogor.

Sitri Sorga, HM Mozart B Danu, Sri Fajar Ayu. 2013. Analisis Komparasi Nilai Tambah dalam Berbagai Produk Olahan Kedelai pada Industri Rumah Tangga di Kota Medan. Journal on Social Economic of Agriculture and Agribusiness Vol 2. No.12

Sugiarto. Herlambang, T,. Brastoro, Sudjana, R., Kelana S., 2005. Ekonomi Mikro. Sebuah Kajian Komprehensif. Penerbit PT. Gramedia Pustaka Utama. Jakarta.

Vinaari Fitriyanti. Blogspot. Com/2012/12/ Hasil Laporan Cara Pembuatan Tahu. Html. 